\title{
INOVASI TEKNOLOGI PENGERINGAN CABE IPTEKS BAGI WILAYAH CSR PT. INDO INVENT DI DESA SUKA DAMAI DAN BUMELA KECAMATAN BILATO KABUPATEN GORONTALO
}

\author{
Fahrudin Zain Olilingo ${ }^{1 *}$, Roy Hasiru ${ }^{1}$, Warno Panigoro ${ }^{1}$ \\ Jurusan Ekonomi, Fakultas Ekonomi, Universitas Negeri Gorontalo, Gorontalo, Indonesia \\ *Penulis Korespodensi: fzo@ung.ac.id
}

\begin{abstract}
Abstrak
Kegiatan Ipteks bagi Wilayah (IbW) PT-PEMDA-CSR yang akan kami laksanakan adalah Peningkatan Kesejahteraan Masyarakat Desa Suka Damai dan Bumela Kecamatan Bilato Kabupaten Gorontalo. Pemerintah Daerah yang mendukung pelaksanaan program ini adalah Pemerintah Kabupaten Gorontalo. Sedangkan Coorporate Social Rensponsibility (CSR) yang juga mendukung program ini adalah CSR dari PT. Indo Invent Gorontalo. Perusahaan PMA dalam pengolahan tembaga. Tujuan umum yang ingin dicapai dalam kegiatan ini adalah untuk mendukung optimalisasi implementasi dan pelaksanaan UU No. 6 tahun 2014 tentang Desa. Sedangkan tujuan khusus yang ingin dicapai adalah dalam rangka mendukung program Pemerintah Kabupaten Gorontalo untuk peningkatan kesejahteraan ekonomi masyarakat dan mengawal pelaksanaan program Cooperative Social Responsibility (CSR) dari suatu perusahaan Penanaman Modal Asing yang bernama PT. Indo Invent Gorontalo. Lokasi pelaksanaan Program IbW PT-PEMDA-CSR ini adalah Desa Suka Damai dan Desa Bumela Kecamaatan Bilato Kabupaten Gorontalo. Hal ini mengingat bahwa, baik Pemda Kabupaten Gorontalo maupun PT. Indo Invent Gorontalo memiliki program yang sasarannya diarahkan pada kedua desa tersebut. Luaran yang dihasilkan dalam program ini adalah meningkatnya keterampilan dan kapasitas kelompok tani dalam manajemen pengelolaan usaha dan penggunaan teknologi tepat guna dalam pengembangan usaha cabe dengan menggunakan inovasi alat pengering cabe energi matahari. Selain daripada itu untuk mendukung usaha pengembangan cabe dibentuk kelembagaan petani pelaku usaha cabe berupa koperasi produksi pertanian. Secara keseluruhannya kegiatan ini telah dapat meningkatkan kesejahteraan masyarakat Desa Suka Damai dan Desa Bumela Kecamatan Bilato Kabupaten Gorontalo. Metode pelaksanaan adalah Bimbingan Teknik cara Pemanfaatan Teknologi Tepat Guna (TTG) Pengelolaan Pasca Panen Usaha Cabe; Pembentukan Koperasi Serba Usaha; dan Pemeriksaan Kesehatan Gratis.
\end{abstract}

Kata kunci: IbW PT, PEMDA, CSR

\begin{abstract}
Science and Technology for Region (IbW) PT-PEMDA-CSR which we will carry out is Improvement of Welfare of Suka Damai Village and Bumela Subdistrict of Bilato Regency of Gorontalo. The local government that supports the implementation of this program is the Gorontalo District Government. While Corporate Social Rensponsibility (CSR) which also supports this program is the CSR of PT. Indo Invent Gorontalo. PMA companies in copper processing. The general objective to be achieved in this activity is to support the optimization of implementation and implementation of Law no. 6 of 2014 on the Village. While the specific goal to be achieved is in order to support the Gorontalo District Government program for improving the economic welfare of the community and guarding the implementation of the Cooperative Social Responsibility (CSR) program of a Foreign Investment company called PT. Indo Invent Gorontalo. The location of the program of IbW PT-PEMDA-CSR is Suka Damai Village and Bumela Village in Bilato District of Gorontalo District. This is given that, both the District Government of Gorontalo and PT. Indo Invent Gorontalo has a program targeted at both villages. The output generated in this program is increasing the skills and capacity of farmer groups in management of business management and the use of appropriate technology in the development of chili business by using innovation of solar chilli dryer. In addition to that, to support the development of chili, there is an institutional establishment of chilli farmers in the form of agricultural production cooperatives. Overall this activity has been able to improve the welfare of the community of Suka Damai Village and Bumela Village, Bilato District, Gorontalo District. The method of implementation is Technical Guidance on Utilization of Appropriate Technology (TTG)
\end{abstract}




\section{Management of Post-Harvest of Chili Enterprises; Establishment of Multipurpose Cooperatives; and Free Medical Checkup.}

\section{Keywords: IbW PT, PEMDA, CSR}

\section{PENDAHULUAN}

Negara kita Republik Indonesia tercinta dengan segala kelebihan dan kekurangannya merupakan Negara yang memiliki penduduk lebih dari 200 juta jiwa dan terdiri beribu - ribu pulau dan suku bangsa. Para pendiri Negara ini dengan bijak menempatkan kondisi Desa sebagai unsur Pemerintah terdepan. Struktur Pemerintahan sedemikian rupa memiliki semangat untuk menjadikan desa sebagai pilar utama pembangunan bangsa, logikanya bila sekitar 80.000 desa di bumi pertiwi ini maju, mandiri, sejahtrera dan demokratis maka menjelmalah Negara Kesatuan Indonesia menjadi bangsa yang besar dan terhormat dalam percaturan bangsa - bangsa di dunia.

Lain yang diharap lain pula kenyataannya, dengan pola sentralistik yang dikembangkan di masa lalu telah menempatkan desa menjadi "pelengkap penderita" yang tidak berdaya, karena segalanya ditentukan dari atas bahkan cenderung segala potensi yang dimilikinya lebih banyak menjadi "Upeti" pada Pemerintah diatasnya. Desa tetap miskin, bodoh dan abdi para pejabat diatasnya yang semakin rakus mengeksploitasi desa.

Dalam rangka menjawab permasalahan tersebut di atas dan guna terciptanya pemberdayaan dan peningkatan posisi tawar pemerintah dan masyarakat desa, maka pemerintah dan DPR RI telah menyepakati lahirnya UU No.6 tahun 2014 tentang desa. UU ini ditandatangani oleh Presiden RI SBY pada tanggal 15 Januari 2014.

Kehadiran UU Desa sebagai landasan hukum penyelenggaraan pemerintahan Desa sekaligus cetak biru pembangunan di desa merupakan catatan bersejarah dalam agenda percepatan pembangunan nasional. UU Desa ini juga merupakan momentum percepatan pembangunan di Desa di seluruh wilayah Indonesia. Amanat UU Desa yang bersifat mandatory menitikberatkan pada tata kelola penyelenggaraan pemerintahan desa, pengelolaan asset dan keuangan desa, pembangunan kawasan desa, kewenangan desa dan perangkat desa. UU ini dalam Pasal 87 juga memungkinkan dibentuknya Badan Usaha Milik Desa (BUMD) untuk mengoptimalkan potensi dan aktivitas ekonomi perdesaan.

Dengan UU Desa ini, penyelenggaran pemerintahan desa diharapkan dapat mengelola wilayahnya secara mandiri termasuk di dalamnya pengelolaan asset, keuangan dan pendapatan desa. Untuk memberi insentif bagi penyelenggaraan Pemerintahan Desa, UU Desa ini memberikan jaminan penghasilan dan sejumlah tunjangan bagi Kepala Desa yang bertugas memimpin penyelenggaraan Pemerintahan Desa.

Beberapa tujuan pengaturan Pemerintahan Desa dalam UU ini antara lain tertuang dalam pasal 4 yakni: Membentuk Pemerintahan Desa yang profesional, efisien dan efektif, terbuka, serta bertanggung jawab; meningkatkan pelayanan publik bagi warga masyarakat Desa guna mempercepat perwujudan kesejahteraan umum; memajukan perekonomian masyarakat Desa serta mengatasi kesenjangan pembangunan nasional; dan memperkuat masyarakat Desa sebagai subjek pembangunan.

Terkait dengan hal tersebut di atas, maka kami kami melaksanakan Program IbW PT-PEMDA-CSR. Adapun Perguruan Tinggi yang terlibat adalah Universitas Negeri Gorontalo sebagai pengusul dan Universitas Gorontalo sebagai perguruan tinggi mitra. Pemerintah Daerah yang mendukung pelaksanaan program ini adalah Pemerintah Kabupaten Gorontalo. Sedangkan Coorporate Social Rensponsibility (CSR) yang juga mendukung program ini adalah CSR dari PT. Indo Invent Gorontalo.

Tujuan umum yang ingin dicapai dalam kegiatan ini adalah untuk mendukung optimalisasi implementasi dan pelaksanaan UU No. 6 tahun 2014 tentang Desa. Sedangkan tujuan khusus yang ingin dicapai adalah dalam rangka mendukung program Pemerintah Kabupaten Gorontalo untuk peningkatan kesejahteraan ekonomi masyarakat dan mengawal pelaksanaan program Cooperative Social Responsibility (CSR) dari suatu perusahaan Penanaman Modal Asing yang bernama PT. Indo Invent Gorontalo.

Lokasi pelaksanaan Program IbW PT-PEMDA-CSR ini adalah Desa Suka Damai dan Desa Bumela Kecamaatan Bilato Kabupaten Gorontalo. Hal ini mengingat bahwa baik Pemda Kabupaten Gorontalo maupun PT. Indo Invent Gorontalo memiliki program yang sasarannya diarahkan pada kedua desa tersebut.

Luaran yang dihasilkan dalam program ini adalah meningkatnya keterampilan dan kapasitas kelompok tani dalam manajemen pengelolaan usaha dan penggunaan teknologi tepat guna dalam pengembangan usaha cabe yaitu dengan menciptakan suatu alat pengering cabe menggunakan energi matahari. Selain daripada itu telah terbentuk kelembagaan petani pelaku usaha cabe yaitu koperasi Pertanian Citra Mandiri Sejahtera. Secara keseluruhannya kegiatan inidapat meningkatkan 
kesejahteraan masyarakat Desa Suka Damai dan Desa Bumela Kecamatan Bilato Kabupaten Gorontalo.

\section{PETA LOKASI IBW PT-PEMDA-CSR}

Lokasi pengambilan batu dan pengolahan tembaga oleh PT. Indo Invent meliputi dua desa yaitu Desa Bumela dan Desa Suka Damai Kecamatan Bilato. Menurut penuturan Sekdes Bumela Wawan Tuna bahwa desa tersebut terdiri atas 5 dusun dihuni oleh $392 \mathrm{KK}$ dengan jumlah penduduk miskin sekitar 50 persen dengan mata pencaharian sebagi petani jagung dan cabe, sekitar 20 persen putus sekolah bahkan ada yang tidak mengenyam pendidikan. Fasilitas pendidikan yang tersedia berupa 1 buah TK PAUD, 2 buah SD sedangkan SMP dan SMA belum ada.

Fasilitas jalan akses desa belum memadai bahkan ada dusun terjauh yaitu Dusun Bolongga $18 \mathrm{~km}$ jalannya susah dijalani kenderaan. Fasilitas air minum belum ada sehingga masyaraakat hanya menggunakan air tanah. Begitu pula fasilitas listrik sebanyak 30 persen masyarakatnya belum menikmati listrik. Untuk fasilitas kesehatan di desa ini sudah ada 1 buah Poskesdes.

Untuk Desa Suka Damai menurut penuturan Kepala Desa Suka Damai Boby Akuba bahwa desa ini dihuni oleh 327 KK dan kehidupan masyarakatnya sekitar 80 persen miskin dan rata-rata mempunyai mata pencaharian sebagai petani jagung dan cabe. Fasilitas pendidikan yang tersedia TK 1 buah, SD swasta 1 buah sedangkan SMP dan SMA belum ada. Belum tersedia fasilitas kesehatan sehingga kalau ada yang sakit berobat ke dukun kampung. Untuk fasilitas air sudah tersedia, tetapi fasilitas listrik sekitar 60 persen penduduknya belum menikmati listrik.

Sesuai izin Peruntukkan Penggunaan Lahan dari Bupati Kabupaten Gorontalo No. 100/Bag.Pem/III/9/2014 bahwa di kedua desa ini yaitu Desa Bumela dan Desa Suka Damai Kecamatan Bilato Kabupaten Gorontalo akan didirikan Pabrik Tembaga yang berorientasi ekspor dan tetap mengacu pada ketentuan perundang-undangan yang berlaku. Bahan Baku pabrik diambil dari sumber batu di lokasi pabrik yaitu Desa Suka Damai dan Desa Bumela Kecamatan Bilato.

Hasil kesepakatan antara Direktur PT. Indo Invent dengan Pemerintah Desa setempat, maka telah disisihkan 5 persen dari keuntungan dialokasikan untuk program CSR dimana hal tersebut tertuang dalam Berita Acara kesepakatan antara kelompok dan perusahaan yang dibuat dan ditandatangani di hadapan Notaris lisa Nento. Adapun program bersama CSR: 1). Pembuatan Poskesdes dengan menempatkan 1 orang dokter dan 1 orang perawat, 2). Pemberian Bea Siswa untuk SD, SMP, SMA bahkan Perguruan Tinggi bagi yang berprestasi 3).
Perbaikan jalan akses 4). Penyediaan sarana air bersih 4). Perbaikan Jalan Akses Desa.

Program perbaikan infrastruktur akan dianggarkan sesuai kebutuhan sedangkan program pemberian bea siswa karena menyangkut penyediaan SDM direncanakan setiap tahun sesuai dengan skala prioritas peserta didik.

\section{METODE PELAKSANAAN KEGIATAN}

Kegiatan pengabdian masyarakat di lokasi dilaksanakan melalui pendampingan, pemberian bimbingan teknis serta bantuan langsung kepada masyarakat terutama yang berkaitan dengan kegiatan ekonomi, kesehatan, pendidikan dan penataan lingkungan yang hidup sehat dan aman. Adapun tahapan kegiatan yang dilakukan adalah:

1. Pendampingan kepada kelompok penanam cabe. Kegiatan yang dilakukan adalah pembentukan kelompok penanam cabe pada Desa Suka Damai dan Bumela. Setelah kelompok terbentuk dilakukan bimbingan teknis secara langsung di lapangan tentang teknik penanaman cabe, pemupukan dan pemetikan serta pembukuan sederhana dari setiiap kelompok

2. Bimbingan teknis Implementasi Pemanfaatan Teknologi Tepat Guna (TTG) Pengelolaan Pasca Panen Usaha Cabe bekerjasama dengan tenaga teknis dari Universitas Gorontalo. Kegiatan ini dilaksanakan dengan tahapan:

a. Persiapan Teknis (Waktu, Lokasi dan Narasumber Kegiatan)

b. Survey Lokasi Pelaksanaan

c. Menghubungi Narasumber

d. Pengelompokkan Peserta Bimtek

e. Persiapan alat dan fasilitas Bimtek

f. Pelaksanaan Bimtek

3. Pembentukan Koperasi Serba Usaha dikalangan Kelompok Tani Cabe. Kegiatan ini dilakukan sesuai dengan tahapan pembentukan Koperasi pada umumnya dengan melibatkan unsur dari Kecamatan dan Dinas terkait di Kabupaten Gorontalo maupun Provinsi Gorontalo yaitu sebagai berikut:

a. Persiapan Pembentukan (Administrasi dan Surat Menyurat)

b. Sosialisasi tentang tata cara pembentukan Koperasi oleh Dinas terkait

c. Pembentukan Koperasi oleh Tim Pelaksana

d. Pengurusan kelengkapan administrasi dan legalitas koperasi

e. Pendampingan dan asistensi pelaksanaan kegiatan perdana Koperasi

4. Peningkatan Derajat Kesehatan dikalangan Kelompok Tani Cabe.

Kegiatan ini dilakukan dengan mendorong perusahaan mitra dan pemerintah Kabupaten Gorontalo untuk melaksanakan program pemeriksaan kesehatan gratis bagi kelompok tani 
cabe. Adapun metode dan tahapannya adalah sebagai berikut:
a. Persiapan pelaksanaan (Administrasi dan Surat Menyurat)
b. Berkoordinasi dengan PT Indo Invent dan Dinas terkait
c. Pembentukan Panitia Pelaksana ditingkat Desa
d. Persiapan Lokasi
e. Persiapan Dokter dan Tenaga Kesehatan
f. Pelaksanaan pemeriksaan kesehatan gratis

\section{LUARAN YANG DIHASILKAN}

Luaran yang dihasilkan dalam program ini secara umum adalah adalah untuk terciptanya optimalisasi implementasi dan pelaksanaan UU No. 6 tahun 2014 tentang Desa. Sedangkan secara khusus adalah meningkatnya peran perguruan tinggi dalam peningkatan kapasitas dan keterampilan masyarakat desa; meningkatnya dan optimalnya pelaksanaan program Pemerintah Kabupaten Gorontalo untuk peningkatan kesejahteraan ekonomi masyarakat; dan suksesnya program Cooperative Social Responsibility (CSR) dari suatu perusahaan Penanaman Modal Asing yang bernama PT. Indo Invent Gorontalo.

\subsection{Luaran Program Perguruan Tinggi}

Program Perguruan Tinggi yang dilaksanakan adalah Program Peningkatan Kapasitas dan Keterampilan Masyarakat Desa melalui bimbingan teknik dalam rangka peningkatan kapasitas dan keterampilan masyarakat dan pendampingan dalam perencanaan, pelaksanaan dan pengawasan program pembangunan desa. Bimbingan teknik dilaksanakan untuk mengembangkan Teknologi Tepat Guna (TTG) dalam pengeringan cabe yang dihasilkan masyarakat. Jumlah petani penanam cabe sebanyak 65 orang petani yang dikelompokkan menjadi 6 kelompok. Rata-rata pemilikan lahan 1 sampai 2 pantango (0,25 s/d 0,5 ha). Produksi per pantango $70 \mathrm{~kg}$ per minggu atau $280 \mathrm{~kg}$ per bulan. Total produksi kelompok sebanyak 65 orang petani adalah $18.000 \mathrm{~kg}$ per bulan. Dengan asumsi rata-rata pemilikan lahan 0,25 ha per orang, maka kisaran pendapatan per bulan untuk 65 orang petani dapat dilihat pada tabe 11 berikut:

Tabel 1. Omzet Produksi dan Pendapatan Petani

\begin{tabular}{cllll}
\hline $\begin{array}{c}\text { Produk } \\
(\mathbf{k g})\end{array}$ & $\begin{array}{l}\text { Harga } \\
\text { (Rp) }\end{array}$ & $\begin{array}{l}\text { Total } \\
\text { (ribuRp) }\end{array}$ & $\begin{array}{l}\text { Pendapatan } \\
\text { /orang } \\
\text { /bulan }\end{array}$ & $\begin{array}{l}\text { Penda- } \\
\text { patan } \\
\text { /orang } \\
\text { / hari }\end{array}$ \\
\hline 18.200 & 5.000 & 91.000 & 1.400 .000 & 46.666 \\
18.200 & 10.000 & 182.000 & 2.800 .000 & 93.333 \\
18.200 & 15.000 & 273.000 & 4.200 .000 & 140.000 \\
18.200 & 20.000 & 364.000 & 5.600 .000 & 166.666 \\
18.200 & 30.000 & 546.000 & 8.400 .000 & 280.000 \\
18.200 & 40.000 & 728.000 & 11.200 .000 & 373.333 \\
18.200 & 50.000 & 910.000 & 14.000 .000 & 466.666 \\
\hline
\end{tabular}

Sumber: Diolah dari data lapangan, 2017.
Hasil perhitungan menunjukkan bahwa harga yang layak dan menguntungkan petani adalah di atas Rp. 30.000.- per kg. Saat harga turun di bawah Rp. 30.000.- per kg, dan produksi melimpah, maka dibutuhkan pengawetan cabe agar tahan lama. Untuk itu Tim Pengabdian Universitas Negeri Gorontalo bekerjasama dengan Universitas Gorontalo telah mengadakan alat pengawetan cabe tenaga surya pengganti arang tempurung bekerja sama dengan Dosen Fakultas Pertanian Universitas Gorontalo bapak Ir. Fadly Abdullah, M.P.

Gambaran singkat mengenai alat tersebut adalah sebagai berikut: Alat tersebut terbuat dari bahan dasar seng plat pakai cerobong untuk penguapan panas dari pengeringan bahan pangan yang mengeluarkan uap air, seng bergelombang untuk daya penampung panas, cat minyak warna hitam supaya panasnya terserap, kayu lata dan kawat ram.

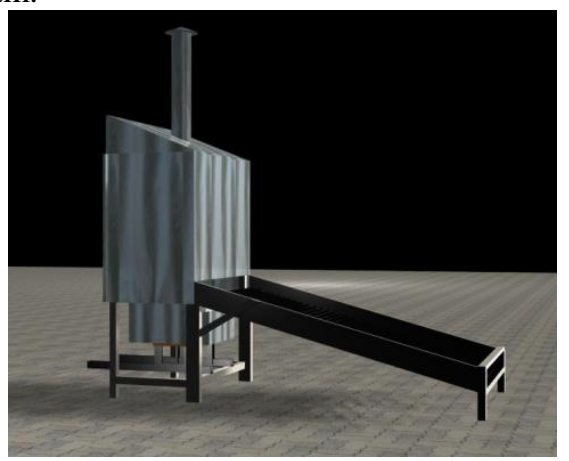

Gambar 1. Alat Pengawetan Cabe

Disainnya di buat menjadi beberapa bagian penting seperti lempengan logam yang bisa menyimpan energi surya masa waktu 12 jam, atap dan tempat penyimpanan cabe dengan kapasitas $30 \mathrm{~kg}$.

Hasil pengawetan cabe selain untuk meningkatkan daya tahan cabe hingga 3 hari, juga produk cabe warnanya menjadi lebih mengkilap sehingga memiliki daya tawar tinggi apabila dipasarkan di pasar moderen. Sebagai gambaran tentang tanaman cabe dapat dilihat pada gambar 2 dan 3 berikut:

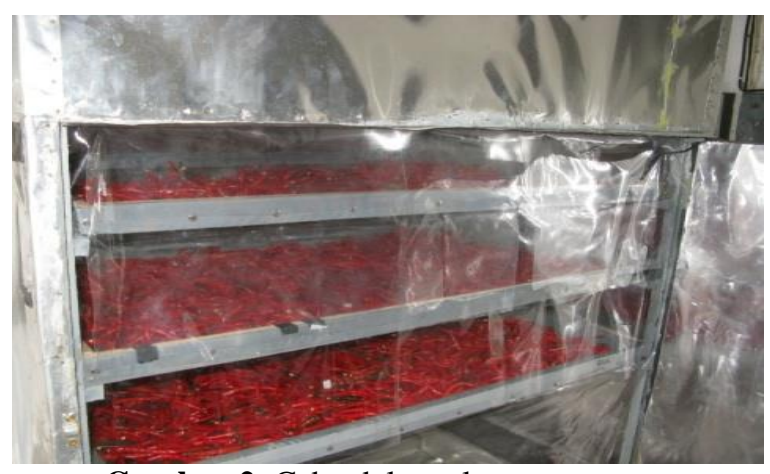

Gambar 2. Cabe dalam alat pengawetan 

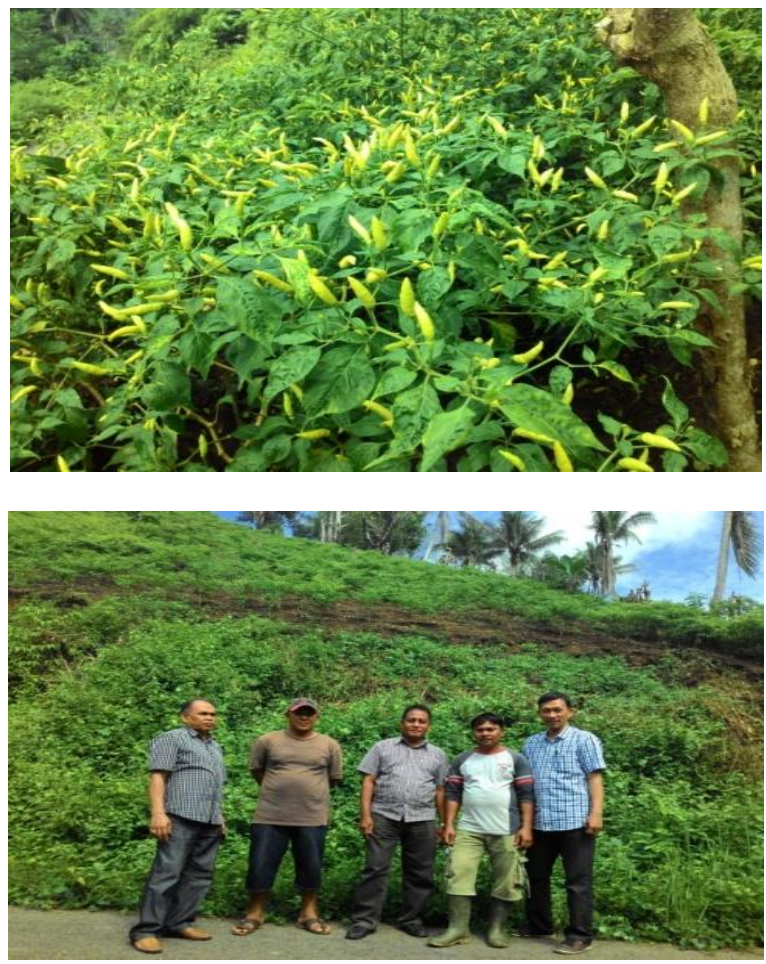

Gambar 3. Tanaman Cabe dan Tim Pelaksana

Selain kegiatan bimbingan teknik teknologi tepat guna pemanfaatan alat pengeringan cabe, juga dilakukan bimbingan teknik Manajemen Pengelolaan Usaha dan Teknik Pemasaran Usaha Cabe. Dalam bimbingan teknik tersebut diperagakan teknik pembukuan sederhana serta manajemen kelompok. Sedangkan pendampingan dalam perencanaan, pelaksanaan dan pengawasan dilakukan secara bersama-sama dengan Pemerintahan Desa, Perusahaan dan kelompok masyarakat pada desa sasaran untuk memastikan bahwa program yang dilaksanakan baik oleh Pemda Kabupaten Gorontalo maupun CSR oleh PT. Indo Invent Gorontalo dapat mencapai sasaran yaitu meningkatnya kesejahteraan masyarakat.

\subsection{Luaran Program Pemerintah Daerah}

Program yang dilaksanakan oleh Pemerintah Daerah Kabupaten Gorontalo adalah Program Wajib Belajar Pendidikan Dasar 9 tahun, Program Upaya Kesehatan Masyarakat, Program Pengembangan Lingkungan Sehat, Program Kerjasama Pendidikan dan Latihan dalam rangka Peningkatan Kesempatan Kerja, Program Pengembangan Kewirausahaan, Program Pengembangan Lembaga Ekonomi Pedesaan, dan Program Peningkatan Produksi Pertanian/Perkebunan. Luaran yang dihasilkan dari program di atas adalah :

1. Menurunnya Angka Putus Sekolah

2. Meningkatnya APK/APM

3. Menurunnya jumlah KK miskin

4. Meningkatnya derajat kesehatan masyarakat desa

5. Meningkatnya kesempatan kerja dikalangan masyarakat desa
6. Meningkatkan kemampuan kewirausahaan masyarakat desa

7. Meningkatnya hasil produksi pertanian/perkebunan

\subsection{Luaran Program CSR PT. Indo Invent}

a. Program Kesehatan

Melalui Program CSR perusahaan yang berlangsung sepanjang perusahaan berdiri dengan menyisihkan dana CSR $5 \%$ dari total keuntungan per tahun maka diharapkan akan terjadi peningkatan derajat kesehatan masyarakat terutama dalam pelayanan kesehatan masyarakat di daerah ini yang secara cepat membutuhkan penanganan.

Pada awal kegiatan masyarakat setempat kesulitan mengakses fasilitas kesehatan karena kedua desa ini belum memiliki fasilitas dan layanan kesehatan yang memadai. Melalui program yang direncanakan secara bersama perusahaan menyediakan infrastruktur kesehatan dan alat-alat kesehatan serta menempatkan 1 orang suster yang memberikan layanan kesehatan seminggu 3 kali.

Untuk meningkatkan pelyanan kesehatan kepada masyarakat telah difasilitasi dan telah berhasil dibangun sebuah Puskesmas Pembantu (Pustu) dengan biaya APBD yang melakukan pelayanan kesehatan setiap hari khusunya di Desa Duka Damai Kecamatan Bilato Kabupaten Gorontalo. Melalui dana CSR dari perusahaan selain memberikan pengobatan kepada masyarakat juga menumbuhkan kesadaran masyarakat untuk hidup sehat dengan memberikan bimbingan untuk hidup sehat dalam lingkungan rumah tangga dan lingkungan tetangga dan masyarakat secara berkelompok.

b. Program Pendidikan.

Pendidikan memegang peranan penting untuk menciptakan sumberdaya manusia yang unggul, memiliki daya saing dalam mengelola pembangunan. Tantangan pembangunan dimasa yang akan datang semakin kompleks di tengah-tengah ancaman persaingan baik tingkat regional, nasional bahkan internasional apalagi setelah nanti diberlakukannya Asean Free Trade tahun 2015.

Pada saat itu pasar tenaga kerja akan dikuasai oleh mereka yang memiliki ilmu pengetahuan dan teknologi cukup tinggi. Saat ini derajat pendidikan di dua desa sasaran CSR ini cukup memprihatinkan karena secara rata-rata luaran SD hanya sampai pada tingkat SMP dan atau SMA dan hanya sedikit yang sampai ke Perguruan Tinggi. Hal ini disebabkan selain karena faktor ekonomi juga karena tingkat kesadaran orang tua terhadap pendidikan relatif rendah atau masih terbawa pemikiran hidup subsisten (yang penting sudah makan). 
Oleh karena itu melalui program CSR dari perusahaan PT. Indo Invent telah dilakukan penyuluhan arti pentingnya pendidikan bagi masyarakat untuk meraih masa depan yang lebih gemilang. Kegiatan ini diharapkan dalam jangka panjang dapat merubah mind set baik bagi anak-anak maupun bagi orang tua sehingga tidak mudah putus asa dan mengutamakan pendidikan sebagai bagian dari kehidupannya.

c. Program Peningkatan Sarana Lingkungan

Lingkungan hidup yang bersih, indah dan sehat memiliki hubungan yang signifikan dengan derajat kehidupan masyarakat. Hubungan ini digambarkan oleh Nurksedalam Sadono Sukirno (1985:217) sebagai suatu masyarakat yang hidup dalam perangkap kemiskinan yaitu suatu masyarakat yang cenderung hidup apa adanya karena kesulitan ekonomi sehingga cenderung hidup tidak sehat, dan cenderung tidak bisa menyekolahkan anaknya dan akhirnya produktifitas dan pendapatannya rendah dan dia akan tetap miskin dengan kehidupan yang tidak sehat dan tidak bercukupan.

Melalui program CSR perusahaan diharapkan selain memberi kesadaran kepada masyarakat sasaran tentang arti hidup bersih dan sehat, juga ada intervensi CSR perusahaan dalam penataan lingkungan hidup masyarakat seperti penataan jalan-jalan desa, sarana air bersih, kamar mandi dan wc, saluran air, tempat pembuangan sampah dll.

\section{KESIMPULAN}

a) Program Pengabdian Masyarakat Ipteks Bagi Wilayah CSR PT. Indo Invent Di Desa Suka Damai Dan Bumela Kecamatan Bilato Kabupaten Gorontalo telah berdampak pada masyarakat terutama dalam peningkatan produksi pertanian khususnya cabe, peningkatan mind set masyarakat dalam pemahaman arti hidup sehat, penataan lingkungan serta pemahaman terhadap pentingnya pendidikan untuk menekan angka putus sekolah

b) Untuk mengawetkan cabe terutama ketika produksi melimpah dan harga turun, maka telah diciptakan alat pengering cabe kerjasama dengan Universitas Gorontalo menggunakan energi surya yang sangat ramah lingkungan dan biayanya terjangkau oleh masyarakat petani dengan hasil pengawetan cabe yang mengkilap dengan mutu yang bisa diterima pasar moderen.

\section{SARAN}

a) Program rintisan pemberdayaan masyarakat Ipteks Bagi Wilayah CSR PT. Indo Invent Di Desa Suka Damai Dan Bumela Kecamatan Bilato Kabupaten Gorontalo hendaknya dapat dilanjutkan oleh Pemda Desa Suka Damai dan Bumela Kecamatan Bilato dan Kabupaten Gorontalo demi peningkatan produksi, derajat pendidikan dan kesehatan masyarakat.

b) Alat pengering cabe diharapkan dibantu pengadaannya oleh dinas terkait dan dapat diberikan kepada petani cabe yang benar-benar membutuhkan disertai dengan pendampingan terhadap pemanfaatan alat tersebut.

c) Perlu dilakukan pembinaan terhadap koperasi Pertanian Citra Mandiri Sejahtera yang telah tebentuk untuk melakukan usaha yang mendukung peningkatan produksi cabe dan jagung serta pemasaran atas produk tersebut samapai pada pasar moderen.

\section{UCAPAN TERIMA KASIH}

Ucapan terima kasih tim tujukan kepada pihak Direktorat Penelitian Dan Pengabdian Kepada Masyarakat yang telah memberikan dana dan LPPM Universitas Negeri Gorontalo yang telah memfasilitasi untuk pelaksanaan pengabdian kepada masyarakat ini.

\section{DAFTAR PUSTAKA}

Bambang Rudito \& Melia, 2013. Cooperate Social Responsibilty, Rekayasa Sains, Bandung.

Batubara, Bobby (2006). Cooperative Social Responsibility Untuk Meningkatkan Produktifitas Perusahaan, (Thesis) Bandung MBA-ITB.

Undang-undang no. 18 tahun 2007 tentang Perseroan Tebatas

Laporan Perkembangan PMA dan PMDN Provinsi Gorontalo Tahun 2011-2012, Badan Investasi Daerah Provinsi Gorontalo, 2013.

Panduan Pelaksanaan Penelitian Dan Pengabdian Kepada Masyarakat Di Perguruan Tinggi Edisi IX, Direktorat Penelitian Dan Pengabdian Kepada Masyarakat,Direktorat Jenderal Pendidikan Tinggi Kementerian Pendidikan dan Kebudayaan, Tahun 2013. 